\title{
For an ecology of scientific work: science, politics and the case of streams Pampa and Luiz Rau in Novo Hamburgo, Brazil
}

\author{
M. Meirelles ${ }^{a}$, V. Pedde ${ }^{b}$ and J. A. S. Figueiredo ${ }^{b *}$ \\ ${ }^{a}$ Centro Universitário La Salle - Unilasalle, Av. Victor Barreto, 2288, CEP 92010-000, Canoas, RS, Brazil \\ bUniversidade FEEVALE, Câmpus II, ERS-239, 2755, CEP 93352-000, Novo Hamburgo, RS, Brazil \\ *e-mail:sganfigue@feevale.br
}

Received: January 17, 2015 - Accepted: May 20, 2015 - Distributed: November 30, 2015

(With 2 figures)

\begin{abstract}
If, like Weber writes, every knowledge is objective in terms of evolving the interests of researchers and the agencies, in this article, we investigate that, which has been researched about two streams: Pampa and Luiz Rau. In doing so, in addition to highlighting what has caught the researchers' attention, this paper manages to point out a few gaps and fruitful fields of study which extend beyond the hard sciences. This study is, therefore, characterized as an essay review paper that sets out to use anthropology of science to think about the limitations and advances the studies about the two streams have achieved, as well as their social impact.
\end{abstract}

Keywords: Pampa Stream, Luiz Rau Stream, Novo Hamburgo, Brazil, anthropology of science, environment.

\section{Por uma ecologia do trabalho científico: a ciência e a política e caso dos arroios Pampa e Luiz Rau em Novo Hamburgo, Brasil}

\section{Resumo}

Se como escreve Weber, todo o conhecimento é objetivo na medida em que envolve interesses de pesquisadores e agências nos questionamos nesse texto sobre, quando falamos nos arroios Pampa e Luiz Rau, aquilo que têm sido pesquisado sobre esses dois arroios. Desta feita, além de colocar em evidência o que têm despertado o interesse, seu mérito reside em apontar algumas lacunas e campos profícuos de estudo que vão para além das ciências duras. Esse estudo se caracteriza, portanto, por um estudo bibliográfico e ensaístico que busca através da antropologia ciência pensar os limites e avanços que se obteve nos últimos anos nesse estudos e seu impacto social.

Palavras-chave: Arroio Pampa, Arroio Luiz Rau, Novo Hamburgo/RS, antropologia da ciência, meio ambiente.

\section{Introduction}

According to Weber, every knowledge is objective when we refer only to the objectives of a specific study, considering that, in its genesis, it is the result of the motivations that led the researcher to investigate a given topic. Therefore, every object of science is, first and foremost, an arbitrary, limited framing of an infinite social reality, so that, in science, there would be no pure knowledge, because knowledge is always charged with meaning, choices of a political, economic, social or cultural nature, etc. The process of building knowledge, under this perspective, would be the result of that, which men, at a given point in their history, consider to be important to know.

In current times, we refer to this as meta-agenda, which is currently determined by the lines of research and financing offered by the main national and international research organs, informing scientists as to what is interesting to research at the moment. Therefore, beyond an individual activity locked away in laboratories and academic offices,

the research activity and that which must be researched about are the results of a political choice with established ends, made by people in various government agencies and also within the scientific committees of these agencies.

However, these political choices are far from arbitrary and, generally, they are based in both public and private interests. In the scope of the former, we have fundamentally that which we refer to as basic research, i.e., high-cost research, such as producing synthetic diamonds for a cutting-edge industry, discovering new materials, etc. In the scope of the latter would be making that "marketable" and "economically viable", after the process has been discovered, once every process or innovation has its cost (Prodanov, 2013). And the first to use it will, by default, pay for the costs of its development, since there are restrictions to its use within the production matrix, at first, which makes it rather expensive. 
However, as time passes and the new process or innovation has been largely adopted by the industry, these technologies tend to become "cheaper" and "more popular", so that, after one or two years, this cost of implementation for the process is often cut down by almost $40 \%$ of its initial cost. A good example of that are capacitive screens, LCD and LED monitors and external mass-storage drives, such as pen-drives, hard disks and high-capacity DVD units.

This article aims to investigate the issue of water and the research about certain water basins, especially concerning that which has been regarded as important to research, based on this interplay of existing interests within the scientific field (Bourdieu, 2007; Latour, 1994, 2000, 2001; Shapin and Schaffer, 2005), in which various interests are faced with one another. In that sense, we will seek to discuss the supposed neutrality of the scientific work - and of that which is considered to be food for thought, making a pun with Levi-Strauss - based on the perspective of Max Weber's comprehensive sociology and on Bruno Latour's proposal of a symmetrical anthropology.

\section{Technological Education, Ifets, R\&d Research Centers and Technical Schools: for What and for Whom?}

In that sense, like Weber (2004) said, we have the fact that capitalist society, given the way it is structure, is prone to training the people it needs in order to reproduce, by economical selection and the defense of capital interests. Additionally, the growing incentive, both from federal, state and municipal governments and from the private initiative, through its class and corporate associations, is a good example of this dynamics. This is manifest in the increasing number of schools, institutes and centers geared at professionalizing, technical education, as well as in the creation of R\&D centers, which become more and more common in major urban centers and medium to large-sized cities.

It should be noted that the individual who devotes himself to the research activity, although often isolated in his lab, chasing the discovery of his lifetime, is never alone. At the tip of his pipette are political, engineering, and material choices, among others. These choices are based on a wide variety of aspects and dimensions of reality, which, by default, organize themselves and establish hierarchies within the scientific field, pointing at different directions and orders for scientific practice.

In that manner, understood from his subjective action, the researcher is never alone and, when shifting from one field to another, such as when a researcher takes over as director of an institute or research center, or even a ministry or funding agency, he brings along an infinity of values and understandings from the world he believes in, which, whether or not we like it, will guide his action and help mold his strategies outside laboratories, into these agencies' political directives, as Latour $(2000,2001)$ describes very well. Their priorities as to what is considered important are informed by that set of beliefs and background and will often differ from those other agents in this same arena - that of directive policies for research centers and institutes - consider to be fundamental.

That having been said, the scientific field, as well as the political, as Bourdieu (2007) has pointed out is a field of permanent dispute, in which the individual and collective interests, whether political, economical or social, of various research groups - which have greater status and power within the scientific field because of their status and prestige - end up overpowering the interests and needs of other groups who are less prestigious within the field. Given their position of power over the latter, the former end up putting the research objects and interests of the less prestigious groups in the background, causing them to be regarded as less important than those of the people occupying prestigious positions, who, in turn, have their research objects and interests regarded as "nobler and more interesting".

Therefore, more than the personal accomplishment of an individual researcher, the discovery of something, such as a new, innovative process, a new material, etc. is, first and foremost, the expression of human, political and economic desires given a priori by different agents who, within the scientific and political arenas, the latter connected to various instances of government and research agencies, define the meta-agenda to be followed. Scientific discovery and the research activity in itself are, therefore, charged with intentionality and purpose.

That having been said, beyond the sum of individual representations, as Durkheim (1970) intended, the objectives of such research and funding agencies and instances would be to, above all, guide the direction of scientific activity by funding that which, by default, is on the meta-agenda of those who dominate the directive instances of those organizations and occupy prestigious positions of power in relation to the other agents - namely researchers. In that manner, those organizations only have meaning and make sense for the agents as holders of a meta-agenda that people in this field operate with and consider to be valid and representative of their own interests.

Therefore, it is understood that, under this perspective, the goal of Federal Institutes of Technological and Upper Education (IFETS), R\&D centers and Technical Schools is to train highly qualified labor geared at the country's industrial, technological development, a purpose that is linked with a policy of internalization of technical courses of secondary school and upper education and the fostering of local development.

\section{On the Constitution of the Field and the Emergence of a New Paradigm about the Environmental Issue}

That having been said, and taking it further, concern around environmental issues has been part of the agenda of a variety of institutions for some time now, and it is present in the political discourse of a large part of the current global political class, in which the so-called green 
parties, as well as countless activists and NGOs and third sector organizations have been gaining space and seeking to expand their influence in order to advance their ideals. However, the environmental theme is also in the repertoire of various sectors of the economy that view environmental issues as a way to add value to their products, processes and services.

We will especially be focusing on this last segment, as this accounts for the largest bottleneck and the greatest environmental impact, because of the products adopted for the production of their products, as much as the greater use of natural and energy resources. However, this is also the sector in which, given the current investment in technology and qualified labor, there has been the most investment and focus on the development of clean technologies.

These technologies have been increasingly appealing to investors, on the one hand, because of the global climate situation and, on the other hand, due to the increased space granted to environmental and ecological issues, which are ever more present in the media and have become ways to "bring in money" and "make money", making it a constant "concern" within the conceptual and worldview horizon of a large portion of the world population.

An example these technologies bringing in money is the case of compensation credits earned for the use of less environmentally polluting technologies. This can be observed by analyzing companies' environmental management history. These analyses have shown that, over the past decades, concern with the environmental issues has been on the rise, as shown in Figure 1, extracted from a specific publication by the Brazilian Service of Industrial Education in the state of Rio Grande do Sul (SENAI-RS) titled 'Implementation of Cleaner Production Programs'.
In that sense, we can observe that, over the past 50 years, there has been a better understanding of the environmental issue, of the need to treat industrial waste and to think about pollution control policies. In a way, this has made the environmental issue tangible, in the sense of thinking about the environment as a heritage to be preserved, as we have already written in another occasion (Meirelles and Pedde, 2014; Pedde et al., 2014).

Above all, under this perspective, it is understood that the use of clean technologies represents a huge paradigm change, following Kuhn's (1997) proposal, in such a way that the implementation of these technologies is geared at "what to do in order not to generate waste" rather than the guiding question of the old paradigm, which used to revolve around "what to do with the waste that is generated". In practical terms, this has generated a profound change of perspective, in such a way that, that, which used to be regarded as a problem and as something that only generated costs to companies, has come to be regarded as an opportunity to think about productive processes and improve them to the point of making this profitable.

But how so? Through the so-called carbon credits, for example, through which developed nations - the top countries in terms of greenhouse gas emissions - buy certifications in the form of investments in projects and processes of Clean Development Mechanisms (CDM). According to Antonio et al. (2012), this is one of the tools that help developed nations reach the emission goals established by the Kyoto Protocol. These certificates grant developed nations the right to emit greenhouse gas, as long as they also finance CDM projects geared at reducing greenhouse gas emissions (GGE). Fundamentally, these credits aim to
The 50 and 60's

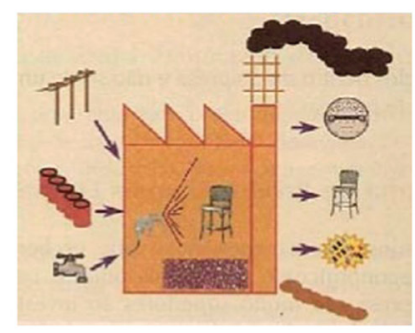

The 70 and 80's

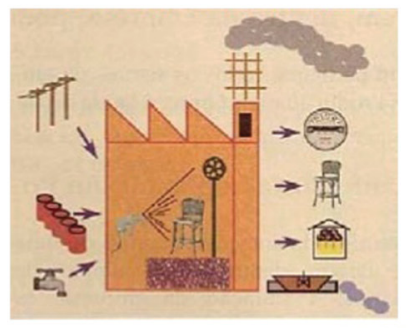

The 90 and 2000's

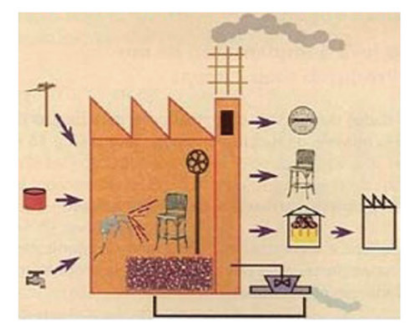

\section{Disposal}

Early development of quality

and emission standards

Free environment or nearly

free environment

Waste dilution and emissions in water and air

Almost complete nonexistence

of corporate responsibility

with environmental impact

\section{Treatment}

Licensing system and environmental impact Reactive attitude: compliance with environmental standards Control at the "end of pipe" Isolated corporate responsibility

\section{Prevention}

Economic instruments and voluntary code of conduct Proactive approach: beyond compliance

Clean Technology/life-cycle assessment Integration of responsibility in corporate structure

Figure 1. Evolution of the environmental issue within companies. Source: SENAI (2003). 
[...] alert nations that polluting industrial processes must be reviewed in order to reconcile socioeconomic development and the need to reduce GGE, seeking to compensate for emissions through a program that sparks, in each nation, political goodwill to review industrial processes and thus reduce pollution and its impact on climate, by compensating for atmospheric emissions that generate a balance between new emissions of air pollutants and their reduction (Antonio et al., 2012, p. 8).

These programs also add value to brands, via a variety of environmental seals, production and quality standards that are regarded as less harmful to the environment. In this case, we refer to productive processes regarded as cleaner and less harmful to the environment, especially when it comes to applying a set of strategic techniques to processes and products aimed at increasing efficiency in the use of raw materials and other inputs required for production, such as water and energy, so that waste generation can be reduced and/or minimized - since such waste is most often disposed of in the environment, whether in the air, land, or water.

In that sense, we could say there are currently two approaches and/or ways of thinking about the issue of waste generation: the traditional one and the logical one. The traditional one, regarded as the simpler one, aims to act only on the solution of the problem of waste generation, without, however, questioning its production process itself. It often represents a significant cost increase when associated with waste management, in the sense that it focuses only on treating the waste, which makes the production process itself more expensive in the long run, expanding the production chain to the treatment of the waste derived from the process itself.

The logical approach, in turn, focuses on the development of solutions connected to the prevention and minimization of waste generation, based on the implementation of more eco-efficient processes. Its efficiency is far greater, in the sense that it assumes changes in the production process and it is also complex, in terms of involving the implementation and development of new production technologies which, in are more expensive in the short run but become cheaper in the long run because they permanently reduce the waste generated. In practice, we understand the implementation of Cleaner Production Programs (CPP) require a profound knowledge of the industrial production processes adopted and constant monitoring and maintenance of the processes within more eco-efficient production systems.

The benefits of CPP include identifying and eliminating wastefulness, minimizing or eliminating (or even reducing) the use of raw materials, waste and emissions considered to be harmful or potentially dangerous to the environment, reducing industrial waste water treatment costs and cutting down on the passives geared at such treatment. This contributes to a better corporate/brand image in the market, increased productivity through process optimization, etc. Furthermore, we must remember that production processes associated with CPP must prioritize the development of a closed production circuit, that does not contaminate the environment while using natural resources with maximum efficiency, as the modern theories of administration advocate.

Therefore, when we reduce polluting emissions and/or waste in the environment, we are also helping preserve the environment in the sense of optimizing the use of raw materials, natural resources and energy. We are especially referring to a more rational use of water. Water consumption is the target of a series of policies geared at preserving watercourses and protecting river sources, as we have stated elsewhere (Meirelles and Pedde, 2014).

That having been said, in the following items, we will focus on to specific issues, investigating the case of two streams that are part of the Sinos river basin, in southern Brazil, namely, streams Pampa and Luiz Rau. The first issue is showing what has been researched about these streams and what the privileged focuses of the analyses have been. For the second issue, the social sciences are called upon to contribute to the debate.

\section{At the Tip of the Pipette, Stream Waters: or, on What Researchers Have Been Researching}

In order to verify the current state of environmental concerns, specifically those in Brazil's upper education and scientific output funding agencies (CAPES and CNPq), it is necessary to conduct a preliminary survey - which is bound to be incomplete, because the updates on CAPES' thesis and dissertations databases is not immediate and involves a series of legal and formal transactions, from defending one's thesis to having it available online - of the defended thesis and dissertations that have, as their research/discussion object, streams Pampa and Luiz Rau, over the past 10 years, at least, in addition to articles published in indexed journals in various areas of knowledge.

Based on the Figure 2 below, extracted from a study conducted by Robaina et al. (2002) about the presence of heavy metals in current sediments as indicators of environmental risk in the Sinos river valley, we can have an idea of the topology of the Sinos river basin and of the extension of stream Luiz Rau, both in relation to other streams and to stream Pampa, which is also the object of this study.

Specifically in relation to the study conducted by the aforementioned authors, there is a high presence of metal sediments in almost all the collection points covering streams Luiz Rau and Pampa, so that both streams present an environmental risk ranging from moderate to high. Of the two streams, Luiz Rau has the most pronounced presence of heavy metals (Chromium, Copper, Lead, Nickel and Zinc) in current sediments, and, therefore, a higher level of untreated industrial waste discharge than stream Pampa.

In another study by Nascimento and Naime (2009) about the contamination process of the waters of Pampa stream, the need to think about man's intervention over water basins is pointed out, once this intervention is increasingly intense. Such intensity is due to the very urbanization process observed in the region for a few decades. 


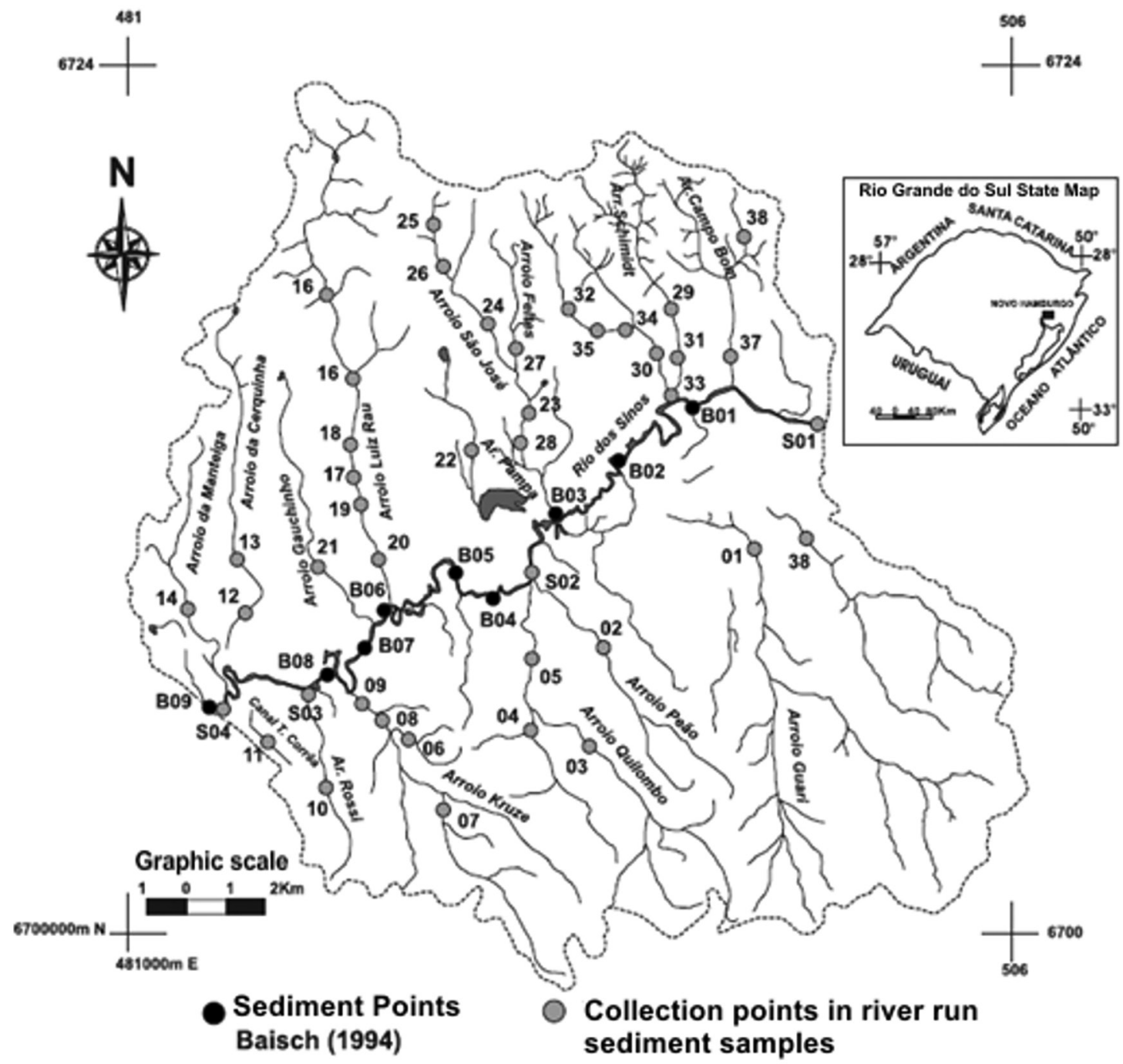

Figure 2. Watercourses in the Sinos river basin, with collection points for the study conducted by Robaina et al. (2002, p. 36).

The increase in population density that accompanies this urban expansion causes an increasing volume of domestic effluents, which contain a high level of polluting elements and are discharged daily in most of the streams in the Sinos river basin ${ }^{1}$.

\footnotetext{
Data presented by a Technical Report from CODEMA (apud Nascimento, 2007) state that, in the state of Rio Grande do $\mathrm{Sul}$, according to a nationwide research conducted on basic sanitation services, is among the five Brazilian states with the lowest rates of treated sewage in the country, with only $22 \%$ of all household sewage and effluents treated before discharge in rivers, creeks, streams, etc. In that sense, and specifically referring to the Sinos river basin, Nascimento (2007, p. 14) estimates that about $84,478 \mathrm{~kg} /$ day of household organic matter find their way to the Sinos river or to the soil of its basin. Using the same criterion, Nascimento (2007, p. 15) also estimates that, in the Pampa stream micro basin alone, about four metric tons of organic matter are discharged every day, which accounts for $5 \%$ of all the organic material discharged in the Sinos river basin, which the micro basin is part of.
}

In parallel with the population increase, there is also a growing volume of industrial activity and the number of industries in the region are producing goods to serve this new population. Because of the intensified industrial activity, there has also been increase in the production of industrial waste and effluents derived from open production chains that also discharge tons upon tons of heavy metals in the Sinos river basin watercourses, as shown by the mapping conducted by Robaina et al. (2002).

In that sense, as the quality of surface water resources (rivers, creeks and watercourses) is reduced, the quality of life of the populations living in their immediate surroundings and of those who consume water and food produced there, because they become much more likely to contract countless infectious diseases due to the discharge of untreated household effluents an to being involuntarily exposed to various carcinogenic and teratogenic agents, especially those associated with the presence of heavy 
metals in the current sediments of streams and other watercourses in the Sinos river.

The metals present in these effluents pose a serious health hazard, because build up in the environment and are bio-accumulative within food chains, as shown by Bidone et al. (1997) in their case study of Tartarugalzinho river, in the state of Amapá, where, according to him,

The mean concentration of $\mathrm{Hg}$ in carnivorous species from this work is similar to that from carnivorous species from Amazon contaminated rivers (Lacerda \& Solomons, 1991; Lacerda et al. 1994; Malm et al., 1996). Among the analyzed fish, 8 species $(50 \%)$ presented $\mathrm{Hg}$ concentrations higher than $500 \mu \mathrm{g} . \mathrm{kg}^{-1}$, the U.S. Food and Drug Administration (FDA) Action Level for concentration of $\mathrm{Hg}$ in fish. Within a given species (eg., Serrasalmus sp. And Chichla sp.), Hg concentrations were positively correlated with fish weight (nonparametric Spearman correlation test: $\mathrm{p}<0.05$ ). Moreover, the $\mathrm{Hg}$ concentration ratio between fish water showed values higher than 50,000. These observations strongly suggest that $\mathrm{Hg}$ is accumulated as $\mathrm{MeHg}$ in the local fish fauna. Moreover it is necessary to consider the lake metabolic processes. Mason et al. (1995) suggested that most of the discrimination between inorganic and $\mathrm{MeHg}$ occurs during trophic transfer while the major enrichment factor is between water and phytoplankton. As a result, $\mathrm{MeHg}$ concentrations in fish are ultimately determined by water chemistry which controls $\mathrm{MeHg}$ speciation and uptake at the base of the food chain (Bidone et al., 1997, p. 13-14).

Additionally, contamination by chemical residues present in the water can also cause serious damage to users even when not ingested, as many of these metals, when used for personal hygiene, can contaminate individuals even by skin contact, as Mirlean et al. (2005, p. 788) have pointed out. Also in that same direction, Teng et al. (2011, p. 658) have ascertained that "[...] the most direct interaction between human activities and the surface water quality took place in the city and its areas surrounding the water." This is due to multiple factors, especially those linked to disorganized economic, industrial and urban development, which, combined with uncontrolled demographic growth, cause greater water consumption and contamination by populations (Almeida et al., 2007; Brilly et al., 2006).

Furthermore, the relationship between water quality and the urbanization process in cities and urban centers is not a new one, and many correlations have already been established. For instance, in the case of the European community, a policy for the monitoring of harmful substances in the water was adopted for the first time almost three decades ago, through Directive 76/464/CEE, according to which a list of 33 substances considered to be harmful had their use regulated and their maximum emission values established for all European countries (Gasperi et al., 2009). In that sense, Gasperi has written (2009, p. 2900) the following:

More recently, on July 17, 2006, the Commission adopted a directive for the purpose of setting mandatory Environmental Quality Standards (EQS) on priority pollutants that Member States must achieve by 2015 in order to ensure a "satisfactory chemical status for surface water". This proposal also requires a gradual reduction in emissions, losses and discharges of all priority substances, along with a phase-out or cessation of emissions, losses and discharges of priority hazardous substances within a period of 20 years. In pursuit of WFD objectives through identifying possible pollutant reduction measures, an accurate knowledge of these substances in the receiving aquatic systems, and more specifically in densely urbanized areas, has definitely proved necessary.

In the case of Brazil, there are not many differences, as heavy metals - the chemical elements whose atomic number is over $22-$, which present health hazards for humans are strictly controlled by specific legislation, including Ordinance no. 2914 from the Brazilian Ministry of Health, regulating the acceptable parameters for drinking water. In the Table 1 below, the acceptable legal parameters for such chemicals are presented.

In that sense, in a monitoring carried out by Nascimento (2007, p. 60 and Ss.) it was found that, in some collection points and in monitoring conducted by other agencies, the total levels of some of these elements were often found to be above the maximum level allowed by the legislation in force. We especially want to draw attention for the levels of Nickel, Chromium and Lead.

Furthermore, given the points made so far, it should be expected that part of the studies regard issues pertaining to water potability, public health, the development of policies that handle these issues and the development of strategies to reduce the emission of industrial waste, which necessarily involves a certain approach of the human sciences pertaining the questions addressed so far. However, as it will be pointed out in the following item, this is not necessarily the case.

Table 1. Standard of Maximum Value Permitted (MVP) for Heavy Metals in Drinking Water.

\begin{tabular}{ccc}
\hline Parameter & Unit & $\begin{array}{c}\text { Maximum value } \\
\text { permitted (MVP) }\end{array}$ \\
\hline Antimony & $\mathrm{mg} / \mathrm{L}$ & 0.005 \\
Arsenic & $\mathrm{mg} / \mathrm{L}$ & 0.01 \\
Barium & $\mathrm{mg} / \mathrm{L}$ & 0.7 \\
Cadmium & $\mathrm{mg} / \mathrm{L}$ & 0.005 \\
Lead & $\mathrm{mg} / \mathrm{L}$ & 0.01 \\
Copper & $\mathrm{mg} / \mathrm{L}$ & 2 \\
Chromium & $\mathrm{mg} / \mathrm{L}$ & 0.05 \\
Iron & $\mathrm{mg} / \mathrm{L}$ & 0.3 \\
Manganese & $\mathrm{mg} / \mathrm{L}$ & 0.1 \\
Mercury & $\mathrm{mg} / \mathrm{L}$ & 0.001 \\
Nickel & $\mathrm{mg} / \mathrm{L}$ & 0.07 \\
Selenium & $\mathrm{mg} / \mathrm{L}$ & 0.01 \\
Uranium & $\mathrm{mg} / \mathrm{L}$ & 0.03 \\
Zinc & $\mathrm{mg} / \mathrm{L}$ & 5 \\
\hline
\end{tabular}

Source: Ordinance MS no. 2914 from December 12, 2011 (Annex VII). 


\subsection{Too much water in the pipette, too little ink in the pen}

A lot has been researched in Brazil in terms of coming to the conclusion that we are hindering water potability and that there are various diseases caused by heavy metal contamination in the water - we will not get into the issue of household effluents in this article - and very little has been invested and researched in terms of changing that picture through actions geared at reducing these rates through a more rational use of natural resources and sensible management of industrial waste.

In that sense, given the disciplinary character of modern science, as pointed out by Latour (1994), we could say most studies and works conducted - whether articles, dissertations or theses - are concentrated in the field of biological and Earth sciences. Few studies venture in the field of applied social sciences, and a small number of these are grounded on the social sciences, history, psychology and education, but only one of them - from the area of healthcare - approaches the effects of the amensalism relationship man establishes with the environment where they live and from which they get the resources to survive ${ }^{2}$, as Table 2 shows.

However, before we present the data from this brief survey conducted to produce this text, we must remember that this work is much more guided by the systematization of some debates that have been taking place in the field of the social sciences about the environmental issue, with a few studies already published, and it aims to, above all, think about the issue of water as a sociological problem, rather than enter the field of hard sciences, in the sense that the rats are not locked in laboratories, under the ideal conditions.

Human beings, who live in society and interact with the environment in a variety of ways, are the ones who create laws and parameters only to disregard them; they are the ones who have been responsible for the death of 100 metric tons of fish a few years back in the Sinos river basin; they are the ones to blame for the overuse of fertilizers and the discharge of untreated sewage directly in rivers, streams and watercourses. In the Guaíba lake basin, for instance, the buildup of phosphorus causes eutrophication of water and the proliferation of certain types of exotic seaweed brought in hulls whose reproduction is favored by eutrophication; as a result, in the warmer months, although this does not compromise the potability of water, it eventually causes an unpleasantly strong odor and taste in drinking water.

It should also be noted that most $(46.9 \%)$ of these publications were made through Universidade do Vale do

\footnotetext{
Amensalism or antibiosis is a non-harmonious ecological relationship that takes place when individuals of a given population secrete or discharge substances that hinder the development of individuals and populations from other species, as is the case of the red tide. Red tide, in turn, is an agglomeration of dinoflagellatemicroplancton that rarely happens during sexual reproduction of some pirophyta that cast the huge amount of zoospores in the waters, releasing toxins that are absorbed by other living beings and end up poisoning them and, consequently, their environment - the waters.
}

Rio dos Sinos (Unisinos). Universidade Feevale comes in second, with $21.9 \%$ of publications. In third place comes Universidade Federal do Rio Grande do Sul, with $20.3 \%$ of the studies produced, followed by Universidade do Estado de São Paulo (USP), Pontifícia Universidade Católica do Rio Grande do Sul (PUC-RS) and Universidade Federal do Mato Grosso (UFMT), which have also produced studies about the Sinos river basin or some of its rivers, streams and watercourses, as shown in Table 3.

Table 2. Number of disciplinary studies on the issue of water and potability for human consumption that focus on the Sinos river basin and its watercourses (2002-2012).

\begin{tabular}{lcr}
\hline & $\mathbf{N}$ & $\mathbf{\%}$ \\
\hline Business administration & 6 & 9.4 \\
Archeology & 2 & 3.1 \\
Biology & 14 & 21.9 \\
Accounting sciences & 1 & 1.6 \\
Rural development & 1 & 1.6 \\
Ecology & 5 & 7.8 \\
Economics & 5 & 7.8 \\
Education & 1 & 1.6 \\
Civil engineering & 5 & 7.8 \\
Production engineering & 2 & 3.1 \\
Entomology & 1 & 1.6 \\
Physical geography & 1 & 1.6 \\
Geology & 1 & 1.6 \\
Technological management & 1 & 1.6 \\
History & 3 & 4.7 \\
Psychology & 1 & 1.6 \\
Environmental quality & 3 & 4.7 \\
Chemistry & 2 & 3.1 \\
Water resources and & 4 & 6.3 \\
Environmental sanitation & & \\
Healthcare & 1 & 1.6 \\
Sociology & 4 & 6.3 \\
Total & 64 & 100.0 \\
\hline Source: Capes' Datase of theses & & \\
\hline
\end{tabular}

Source: Capes' Database of theses and dissertations; Scielo; Google Scholar, Local libraries and collections from universities in Porto Alegre and Metropolitan Region, 2014.

Table 3. Higher Education Institutions (HEI) that have output focused on the Sinos river basin and its watercourses (2002-2012).

\begin{tabular}{lcr}
\hline & $\mathbf{N}$ & $\mathbf{\%}$ \\
\hline FEEVALE & 14 & 21.9 \\
PUC-RS & 2 & 3.2 \\
UFMT & 1 & 1.6 \\
UFRGS & 13 & 20.3 \\
UNISINOS & 30 & 46.9 \\
USP & 4 & 6.3 \\
Total & 64 & 100.0 \\
\hline
\end{tabular}

Source: Capes' Database of theses and dissertations; Scielo; Google Scholar, Local libraries and collections from universities in Porto Alegre and Metropolitan Region, 2014. 
Table 4. Quantitative analysis of theses, dissertations and articles published in qualified indexed journals (2002-2012) focusing on the Sinos river basin and its watercourses.

\begin{tabular}{lcc}
\hline & N & \% \\
\hline Articles & 19 & 29.7 \\
Dissertations & 36 & 56.3 \\
Theses & 9 & 14.1 \\
Total & 64 & 100.0 \\
\hline
\end{tabular}

Source: Capes' Database of theses and dissertations; Scielo; Google Scholar, Local libraries and collections from universities in Porto Alegre and Metropolitan Region, 2014.

Analyzing what has been written about the Sinos river basin, we could observe that, out of the 64 publications found, most consist of dissertations and theses, with a greater prevalence of dissertations than theses on the topic. Likewise, about a third of the output mapped is made up of articles published in journals, which signals a growing concern with issues pertaining to the Sinos river basin, as well as the fact that the research these articles report on are being funded, since publications are a requirement to receive a large number of research grants from funding agencies, both from Brazil and from overseas, as shown in Table 4.

\section{Final Remarks}

As we have pointed out in this paper, the knowledge production process is not unbiased from value judgments and, most times, it is linked to the political and economical interests of researchers, funding agencies and the State itself, which offers resources through specific grants to fund research in various universities, laboratories and research centers. It can also be observed that the issue of water is regarded as a scientific problem that has earned the attention of hard sciences but it has not established itself within the social sciences as a sociological problem, as we have already pointed out elsewhere (Ávila et al., 2013).

In that sense, a few studies produced by social sciences researchers in some universities in the Sinos river valley region have been raising the issue of the environmental hazard inherent to the relationship man establishes with the environment as something worthy of greater attention from the social sciences in general and specifically from sociology, as is the case of the environmental hazard issue Figueiredo (2014) has taken up.

From this point on, we believe the challenge is, above all, in thinking about the environmental issue based on other biases and its interfaces with education, anthropology and public policy. These issues have been worked on by a few of the researchers referenced in this paper, through research financed by Universal Grant 14/2014. This research aims to think about the way these different notions become tangible in the social and educational space, especially as a way to increase the efficiency of existing policies in the medium and long term. It also aims to bring people into the environmental arena who have, for a long time, been silenced in these discussions, either for lack of knowledge and background or for sheer ignorance.

\section{Acknowledgements}

This paper was produced with the support of CNPq through Universal Grant 14/2014 and CAPES throught ANA-CAPES/DEB Grant 18/2015.

\section{References}

ALMEIDA, C.A., QUINTAR, S., GONZALEZ, P. and MALLEA, M.A., 2007. Influence of Urbanization and Tourist Activities on the Water Quality of the Potrero de los Funes River (San LuisArgentina). Environmental Monitoring and Assessment, vol. 133, no. 1-3, pp. 459-465. http://dx.doi.org/10.1007/s10661-006-96003. PMid:17294278.

ANTONIO, A.C., ANDRADE, B.C., PAIVA, E.F., FACCHINI, F.D., SILVA, F.S. and SOUSA, G.H., 2012 [viewed 17 January 2015]. Crédito de carbono: investimento sustentável [online]. Rio de Janeiro: FGV. Available from: http://migre.me/onK8F

ÁVILA, V., MEIRELLES, M. and RAIZER, L., 2013. Sociologia, meio ambiente e desenvolvimento sustentável. In: M. MEIRELLES, L. RAIZER, L.H. PEREIRA and J.R. LOPES. Ensino de sociologia: educação, patrimônio e meio ambiente. Porto Alegre: Vangraf/ Laviecs, pp. 153-170.

BIDONE, E.D., CASTILHOS, Z.C., SANTOS, T.J.S., SOUZA, T.M.C. and LACERDA, L.D., 1997. Fish contamination and human exposure to mercury in Tartarugalzinho River, Amapa State, Northern Amazon, Brazil: a screening approach. Water, Air, and Soil Pollution, vol. 95, no. 1-2, pp. 9-15. http://dx.doi. org/10.1007/BF02409640.

BOURDIEU, P., 2007. O poder simbólico. Rio de Janeiro: Bertrand Brasil. 311 p.

BRILLY, M., RUSJAN, S. and VIDMAR, A., 2006. Monitoring the impact of urbanization on the glinscica stream. Physics and Chemistry of the Earth, vol. 31, no. 17, pp. 1089-1096. http:// dx.doi.org/10.1016/j.pce.2006.07.005.

DURKHEIM, E., 1970. Sociologia e filosofia. Rio de Janeiro: Forense. 99 p.

FIGUEIREDO, J.A.S., 2014. La cuestión del riesgo industrial, tecnológico y ambiental: ¿Indiferencia o necessidades insatisfechas? Porto Alegre: Cirkula. 135 p.

GASPERI, J., GARNAUD, S., ROCHER, V. and MOILLERON, R., 2009. Priority pollutants in surface waters and settleable particles within a densely urbanised area: Case study of Paris (France). The Science of the Total Environment, vol. 407, no. 8, pp. 2900-2908. http://dx.doi.org/10.1016/j.scitotenv.2009.01.024. PMid:19223062.

KUHN, T.S., 1997. A estrutura das revoluções científicas. São Paulo: Perspectiva. $257 \mathrm{p}$.

LATOUR, B., 1994. Jamais fomos modernos: ensaio de antropologia simétrica. São Paulo: Ed. 34. 149 p.

LATOUR, B., 2000. Ciência em ação: como seguir cientistas e engenheiros sociedade afora. São Paulo: Ed. da UNESP. 438 p.

LATOUR, B., 2001.A esperança de Pandora: ensaios sobre a realidade dos estudos cientificos. Bauru: EDUSC. 370 p.

MEIRELLES, M. and PEDDE, V., 2014. Ver, tocar, preservar: pensando a noção de patrimônio a partir de sua tangibilidade. Estudos de Sociologia, vol. 1, no. 20, pp. 1-20. 
MIRLEAN, N., MACHADO, M.I., OSINALDI, G.M., DEMOLINER, A. and BAISCH, P., 2005. O impacto industrial na composição química das águas subterrâneas com enfoque de consumo humano (Rio Grande, RS). Quimica Nova, vol. 28, no. 5, pp. 788-791. http://dx.doi.org/10.1590/S0100-40422005000500010.

NASCIMENTO, C.A. and NAIME, R., 2009. Panorama do uso, distribuição e contaminação das águas superficiais no Arroio Pampa na bacia do Rio dos Sinos. Estudos Tecnológicos, vol. 5, no. 1, pp. 101-120.

NASCIMENTO, C.A., 2007. Arroio Pampa: condição atual e sua contribuição para as águas do Rio dos Sinos. Novo Hamburgo: Universidade Feevale, 108 p. Dissertação de Mestrado em Qualidade Ambiental.

PEDDE, V., MEIRELLES, M. and FIGUEIREDO, J.A.S., 2014. A água enquanto um patrimônio tangível da humanidade: meio ambiente, patrimônio, educação e políticas públicas. In: M. MEIRELLES, C.A.S. FIGUEIREDO and G.R. SCHWEIG. Direitos humanos e sociais: educação, patrimônio e meio ambiente. Porto Alegre: Cirkula, pp. 219-242.

PRODANOV, C.C., 2013. Ciência, tecnologia e inovação: ferramentas para o desenvolvimento da sociedade. In: M. MEIRELLES, D.G. MOCELIN, L. RAIZER, V. PEDDE and G.R. SCHWEIG.
Sociologia: Trabalho - Ciência - Cultura - Diversidade. Porto Alegre: Cirkula, pp. 163-180.

ROBAINA, L.E., FORMOSO, M.L.L. and PIRES, C.A.F., 2002. Metais pesados nos sedimentos de corrente, como indicadores de risco ambiental - Vale do Rio dos Sinos, RS. Revista do Instituto Geológico, vol. 23, no. 2, 2002.

SHAPIN, S. and SCHAFFER, S., 2005. El Leviathan y la bomba de vacio: Hobbes, Boyle y la vida experimental. Bernal: Universidad de Quilmes. $505 \mathrm{p}$.

SERVIÇO NACIONAL DE APRENDIZAGEM INDUSTRIASENAI, 2003. Implementação de Programas de Produção mais Limpa. Porto Alegre: Centro Nacional de Tecnologias Limpas SENAI-RS/UNIDO/INEP, pp. 9.

TENG, Y., YANG, J., ZUO, R. and WANG, J., 2011. Impact of urbanization and industrialization upon surface water quality: a pilot study of panzhihua mining town. Journal of Earth Science, vol. 22, no. 5, pp. 658-668. http://dx.doi.org/10.1007/s12583011-0217-2.

WEBER, M., 2004. A objetividade do conhecimento nas ciências sociais. In: G. COHN, org. Max Weber: sociologia. São Paulo: Ática, pp. 79-127. 